\title{
Therapeutic Potential of Folk Plants Used Against Pathogenic and Opportunistic Free Living Amoeba (Acanthamoeba, Balamuthia and Naegleria); A Review
}

\author{
Tania Tanveer ${ }^{1,3}$, Abdul-Aziz A. Bin-Dukhyil ${ }^{1}$, Salik Nawaz ${ }^{2}$ and Abdul Matin ${ }^{13 *}$ \\ ${ }^{1}$ Department of Medical Laboratory Sciences, College of Applied Medical Sciences, Majmaah University, Majmaah, 11952, Saudi Arabia \\ ${ }^{2}$ Department of Pharmaceutical Sciences, University of the Punjab, Lahore, Pakistan \\ ${ }^{3}$ Department of Medical Lab Technology, The University of Haripur, Haripur, Khyber Pakhtunkhwa, 22620, Pakistan
}

Submission: December 18, 2017; Published: February 21, 2018

*Corresponding author: Abdul Matin, Department of Medical Laboratory Sciences, College of Applied Medical Sciences, Majmaah University,

Majmaah, 11952, Saudi Arabia, Tel: +0966 538569781; Email: amawan@live.co.uk

\begin{abstract}
Free living amoebae (FLA) are opportunistic protozoa which are widely spread in our environment. Among these, three genera Acanthamoeba, Balamuthia and Naegleria are responsible for life threatening human brain infections involving central nervous system (CNS) with poor diagnosis. This is also contributed to poor understanding of the pathogenicity of FLA and limited availability of therapeutic options against them. The purpose of this review is to document the medicinal plants used against free living amoeba and critically review the literature on the anti-FLA properties of folk plants against emerging FLA infections. Information regarding FLA was collected from scientific databases like PubMed and scientific literatures based on published papers from Elsevier, Springer, Wiley publishers. An in-depth analysis of previous studies was undertaken and future prospective is considered. Acanthamoeba has been found the mostly studied FLA so far with regards to folk plant extract trails and literature does not describe a single report against Balamuthia and Naegleria. Among all folk plants Allium sativum, Peganum harmala, Origanum syriacum, Arachis hypogaea L., Salvia caespitose, and Melissa officinalis have shown optimal anti-Acanthamoeba effects in vitro. Folk plants and their products could be a potential candidate for the therapeutic drug discovery against FLA. To the best of our knowledge, this document is the first extensive review regarding the utilization of folk plants against FLA in literature.
\end{abstract}

Keywords: Free living amoeba; Acanthamoeba; Balamuthia; Naegleria; Granulomatous amoebic encephalitis; Balamuthia amoebic encephalitis; Primary amoebic meningoencephalitis; Folk plants

Abbreviations: BAE: Balamuthia Amoebic Encephalitis; CNS: Central Nervous System; DNA: Deoxyribonucleic Acid; ER: Endoplasmic Reticulum; FLA: Free Living Amoeba; HCEC: Human Corneal Epithelial Cells; HIV: Human Immunodeficiency Virus; GAE: Granulomatous Amoebic Encephalitis; MIC: Minimal Inhibitory Concentration; PAM: Primary Amoebic Meningoencephalitis; RNA: Ribosomal Ribonucleic Acid

\section{Introduction}

Free living amoebae (FLA) are opportunistic protozoa and ubiquitous which are widely spread in our environment ultimately present in various types of soil, water and air. Among these, three genera Acanthamoeba, Balamuthia and Naegleria can potentially cause life threatening human brain infections involving central nervous system (CNS) in humans and animals [1-3]. Because most of the infections caused by these amoebae are ultimately fatal, diagnosis is often made at autopsy, even in developed countries where sophisticated diagnostic facilities are readily available. However, in Africa and Asia, where HIV/ AIDS is epidemic, it is quite possible that majority of cases have gone undetected. This may be due to a number of reasons like (i) lack of expertise about these amoebae (ii) cultural and financial barriers that prevent autopsies. The actual incidence of protozoan diseases is therefore not really known.

In 1930, Acanthamoeba were discovered as eukaryotic cell culture contaminants of yeast and were sited in the genus Acanthamoeba [4-6]. Acanthamoeba is facultative pathogen and well-known as an agent of granulomatous amoebic encephalitis (GAE), a fatal disease of the central nervous system which always lead to death $[7,8]$. In addition it may cause keratitis, a painful sight-threatening disease mostly related to contact lens wearer. Acanthamoeba sp is widely spread in our surroundings like air, water and soil thus play a pivotal predatory role in 
ecosystem. Acanthamoeba consists of two stages in its life cycle cyst and trophozoites (Figure 1a). Under favourable conditions it survives as a trophozoite thus feeds to live and reproduce. It is transformed into a dormant cyst under unfavourable conditions [7]. Acanthamoeba keratitis is differentiated by photophobia, ophthalmalgia, blue-red vision and blood extravasations. Improper use of contact lenses or corneal trauma results in keratitis. Fever headaches, neurological disorders, such as disorientation, hallucinations and vision disorders and coma are clinical symptoms of human GAE [2].

For the first time in 1986, Balamuthia mandrillaris was isolated from remains of a mandrill baboon (Papio sphinx) brain tissue that died due to a neurological disease at the San Diego Zoo Wild Animal Park in California, USA. Later on in 1991, Balamuthia mandrillaris was linked with deadly human infections (Balamuthia amoebic encephalitis) which involved the CNS $[9,10]$. It has two stages of life cycle known as cyst and trophozoite. Cysts, become visible as a double walled, the outer wall being wavy and the inner wall round, when examines under a light microscope. However, ultra-structural studies have shown that cyst wall possess three layers: 1. ectocyst (an outer thin and irregular layer), 2. endocyst (an inner thick layer) and 3. mesocyst (a middle amorphous fibrillar layer).

Balamuthia mandrillaris has been isolated from soil so far [11]. Under unfavorable ecological conditions, for example extremes in temperature or $\mathrm{pH}$, lack of nutrients, excess of waste products or overcrowding of cells, trophozoites convert into dormant or cysts through a process named as encystment. Encystment guarantees the survival of the amoeba in unfavorable ecological conditions (Figure 1b \& 1d).

Balamuthia amoebic encephalitis (BAE) is a chronic disease which may last from 3 months to 2 years, and always end up to the patient's death. Unlike, Acanthamoeba encephalitis, BAE has been reported both in immunocompromised people and those with normal immunity, suggesting the virulent potential of this amoeba [11-13]. BAE has been identified in patients suffering from human immunodeficiency virus (HIV)-infected patients, cancer, diabetes, or alcohol and drugs abusers. So far, about 120 cases worldwide have been identified, but the exact number of BAE cases may never be recognized which may be due to a lack of awareness about infection and amoeba, poor diagnosis methods and poor public health systems, particularly in under developed countries. Mixtures of drugs are being used for the treatment against this amoeba with very partial success and this is a growing concern in the current medical profession [14]. The patients may show such symptoms from several weeks to months. Some patients sometimes display hemi-paresis and weakness on one part of the face or body, along with restrictions in patient's movement. The patient's conditions started to deteriorate further with lack of response to stimuli along with pulmonary oedema or pneumonia, focal seizures, photophobia, and finally resulting in death $[15,16]$.
The genus Naegleria comprised of a group of FLA found in various habitats all over the world. Naegleria spp. has been isolated from various environmental recourses like domestic water supplies, ponds, freshwater lakes, swimming pools, thermal pools, soil, and dust [17-19]. Naegleria fowleri may cause primary amebic meningoencephalitis (PAM), a fast deadly disease of the CNS which mostly identified among children and young adults with a history of water sports. Naegleria sp have three morphological stages in the life cycle of,

First human infection caused by Naegleria fowleri was described in South Australia by Fowler and Carter [20]. In addition to that PAM cases have also been connected to domestic water supplies [21]. PAM hits in immune-competent individuals and draw out a more rapid disease course. Naegleria infection is commenced by the introduction of water holding amoeba into the nasal cavity of the host. Amoebae attaches to the nasal mucosa, travel along with the olfactory nerves, pass through the cribriform plate, and enter into the brain. Once Naegleria is in that compartment, the amoebae cause massive tissue damage and inflammation. PAM can be distinguished by severe frontal headache, fever, nausea and vomiting, stiff neck, and rarely seizures. Furthermore, the acute hemorrhagic necrotizing meningoencephalitis followed by the invasion of the CNS usually results in death 7-10 days post-infection [1,2,22,23].

1). a trophozoite, 2). a flagellate, and 3). a cyst (1) (Figure 1C) .

There have been a number of reports showing folk plants and their extracts have been used in vitro trails against Acanthamoeba. But this is quite surprising that there is not a single report of any folk plant used against Balamuthia, Naegleria and Sappinia which may be due to many reasons. According to our understanding the other amoeba are very difficult to culture (fastidious organisms) as compared to Acanthamoeba. Secondly Balamuthia has only specie reported so far. Furthermore Naegleria has a complex life cycle consisting of three life stages which make this organism difficult to handle and work with. In contrast 24 species and 17 genotypes of Acanthamoeba [24] has been reported and very easy to culture in laboratory environment that will be one of the reason of the researcher choice for folk medicine trail.

Interest of scientific community to study Acanthamoeba has developed enormously. Acanthamoeba has gained attention from the large scientific community investigating their biochemistry, environmental biology, physiology, cellular microbiology, molecular biology and cellular interactions. This is because of their adoptable characteristics in natural environment. It acts as vectors and reservoirs for pathogenic bacteria and cause serious and life threaten human diseases such as blinding keratitis and deadly encephalitis respectively. Therefore the current review will be mainly focused on Acanthamoeba as in literature only folk plants were used against this amoeba. This review will 
summarize the amoebicidal activity of folk plants which have been studied so far against Acanthamoeba in vitro.

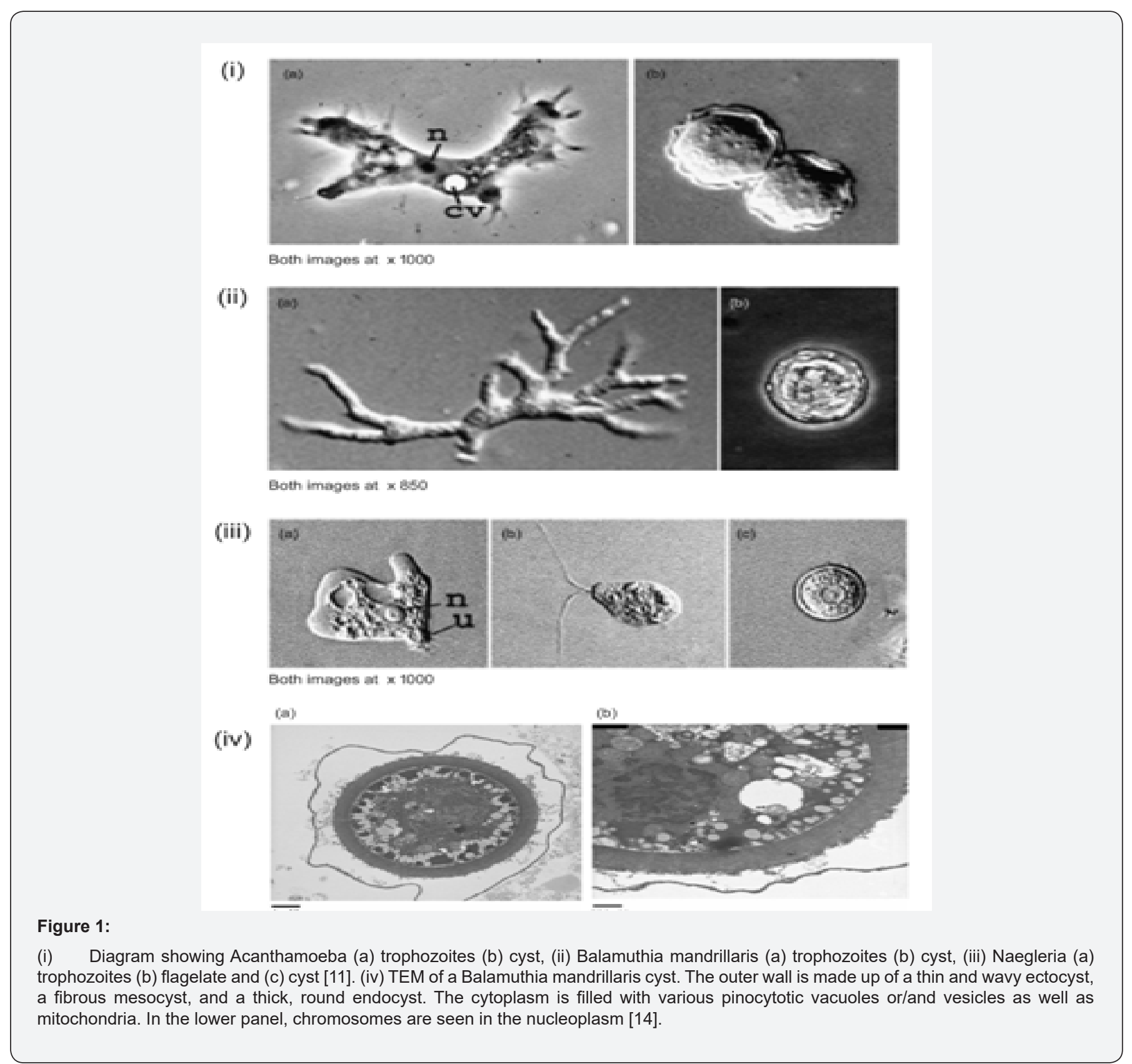

\section{Research Trends in Amoebagenesis}

During the past few decades, a gradual increase in scientific interest among the scientific community has been observed regarding FLA (Figure 2). Among three protozoa, Acanthamoeba has obtained great attention among scientists. Moreover, all the folk plants were used against Acanthamoeba in the literature (Figure 3a \& 3b). The major reason behind its fame is its vast frequency in our environment. Based on its $18 \mathrm{~S}$ rRNA sequence, 24 species which belong to three morphological groups and 17 genotypes have been identified to date. Furthermore, so far about 400 victims of Acanthamoeba infections have been identified all over the world. Recently for the first time both pathogenic and non-pathogenic genotypes have been isolated from various water supplies in Pakistan [24]. All the features of FLA are described in detail in Table 1. For advancement in the outcome of the diagnosis and management of protozoan infections requires new therapeutic approaches. In this regard a better understanding of the amoebic pathogenic mechanisms is required. In the present review we will discuss the current status of knowledge of the new therapeutic approaches (folk plants) used to evaluate their effects against protozoa. We analyzed and documented the effects of folk plants in selected clinically important protozoa Acanthamoeba. 


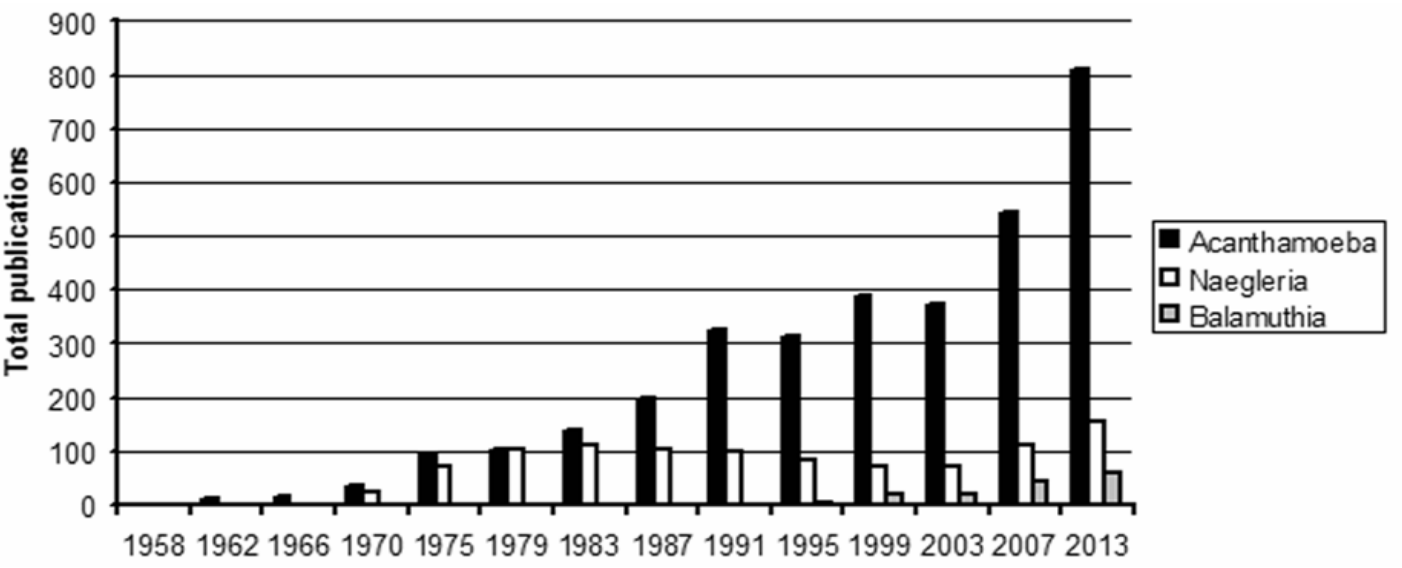

Figure 2:

The number of available published articles on FLA. Data for Acanthamoeba, Balamuthia and Naegleria were collected from PubMed, i.e.http://www.ncbi.nlm.nih. gov/entrez/query.fcgi which clearly demonstrates interest of scientific community in free living amoeba (FLA) duringthe past few decades (visited on January 11, 2013).

(i)

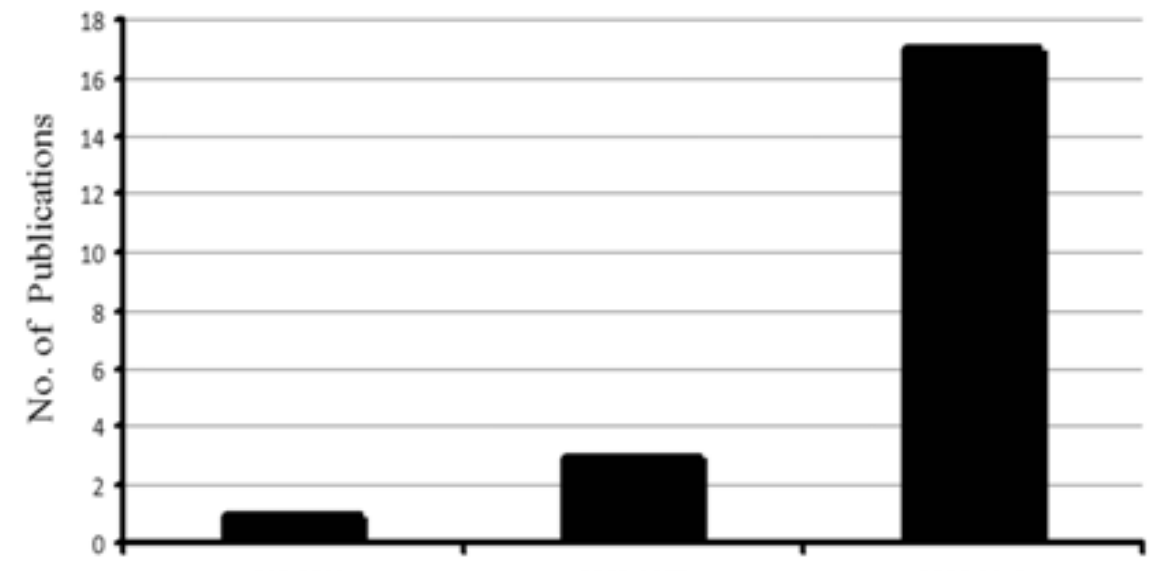

1998-2002

2003-2007

2008-2012

(ii)

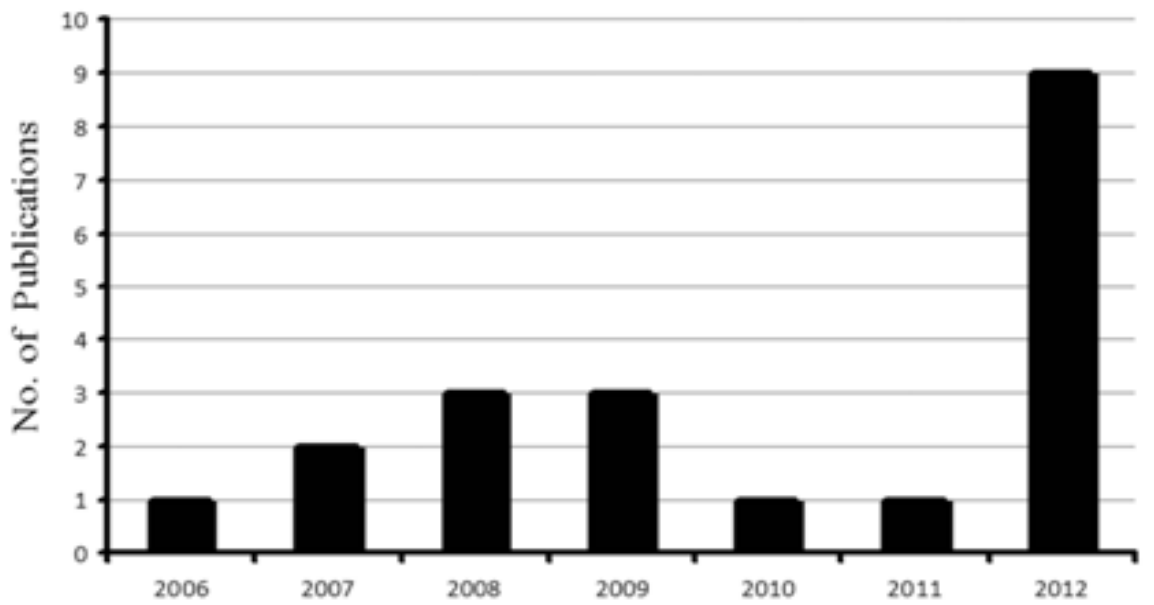

Figure 3: Graph showing trend of publications on in vitro trail of folk plant against Acanthamoeba.

(i) Over all trends of publications on folk plant extracts trails against Acanthamoeba from 1998 till 2012.

(ii) Recent rising trend of folk plant extracts trails against Acanthamoeba started from 2006-12 in literature. 


\section{International Journal of Cell Science \& Molecular Biology}

Table 1: Salient features of members of free living amoeba family.

\begin{tabular}{|c|c|c|c|c|}
\hline S No & Salient Features & Acanthamoeba & Balamuthia & Naegleria \\
\hline 1 & Growth medium & $\begin{array}{l}\text { It can be grown on non- } \\
\text { nutrient agar plate coated } \\
\text { with bacteria, mammalian cell } \\
\text { cultures and axenic medium. }\end{array}$ & $\begin{array}{l}\text { Axenic medium and } \\
\text { tissue culture cells }\end{array}$ & $\begin{array}{l}\text { It can be grown on non- } \\
\text { nutrient agar plate coated } \\
\text { with bacteria, tissue culture } \\
\text { cells, cell free axenic medium, } \\
\text { chemically defined medium }\end{array}$ \\
\hline 2 & Culturing temperature & $30^{\circ} \mathrm{C}$ or above & $37^{\circ} \mathrm{C}$ & $45^{\circ} \mathrm{C}$ \\
\hline 3 & Life stages & $\begin{array}{l}\text { Two stages: cyst and } \\
\text { trophozoites }\end{array}$ & $\begin{array}{l}\text { Two stages: cyst and } \\
\text { trophozoites }\end{array}$ & $\begin{array}{l}\text { Three stages: cyst, trophozoites } \\
\text { and flagellate stage }\end{array}$ \\
\hline 4 & $\begin{array}{l}\text { Food in natural } \\
\text { environment }\end{array}$ & Bacteria & $\begin{array}{l}\text { Mainly bacteria } \\
\text { but to some extent } \\
\text { Acanthamoeba }\end{array}$ & Bacteria and organic matter \\
\hline 5 & $\begin{array}{l}\text { Environmental isolation } \\
\text { sources }\end{array}$ & $\begin{array}{c}\text { Variety of soil, air, water } \\
\text { sources i.e, bottled mineral } \\
\text { water, cooling towers, air } \\
\text { conditioning units, dialysis } \\
\text { machines, bacterial, fungal } \\
\text { and mammalian cell cultures } \\
\text { etc. }\end{array}$ & Soil and dust & $\begin{array}{l}\text { Swimming pools, ponds, hot } \\
\text { springs, thermally polluted } \\
\text { streams, rivers and various } \\
\text { types of soil etc. }\end{array}$ \\
\hline 6 & Clinical Isolation source & Brain, lung, skin, cornea & Brain & $\begin{array}{c}\text { Nasal mucosa, nasal passages, } \\
\text { brain tissue }\end{array}$ \\
\hline 7 & Reported infections & $\begin{array}{l}\text { Ganulomatous amoebic } \\
\text { encephalitis, Amoebic } \\
\text { keratitis, Cutaneous } \\
\text { acanthamoebiasis }\end{array}$ & $\begin{array}{l}\text { Balamuthia amoebic } \\
\text { encephalitis, Skin } \\
\text { ulceration }\end{array}$ & $\begin{array}{l}\text { Primary amoebic } \\
\text { meningoencephalitis }\end{array}$ \\
\hline 8 & Species identified so far & More than 24 species & $\begin{array}{l}\text { Single specie: Balamuthia } \\
\text { mandrillaris }\end{array}$ & 30 species \\
\hline 9 & $\begin{array}{l}\text { Reservoir for pathogenic } \\
\text { microorganisms }\end{array}$ & $\begin{array}{l}\text { Echo-virus, mimivirus, } \\
\text { adenovirus, coxsackie etc. }\end{array}$ & $\begin{array}{l}\text { Legionella, Simkania } \\
\text { negevensis etc. }\end{array}$ & Legionella pneumophila \\
\hline
\end{tabular}

\section{Therapeutics}

Unlike other two protozoa, various treatments have been reported to cure Acanthamoeba infections like successful chemotherapy has been done with extremely toxic drugs commonly used for disinfection, e.g. chlorhexidine derivatives but the percentage of success is very low as mostly patients die during chemotherapy $[25,26]$. Some of the successful treatments of these two infections in immunocompetent individuals have been documented with combined therapy, only if started at initial stage of the disease as ineffectiveness increases in later stages [27]. Successful treatments have been documented with use of a mixture of cationic antiseptics (polyhexamethylene biguanide, chlorhexidine) which obstruct the membrane functions, aromatic diamidines (propamidine isethionate, hexamidine, pentamidine) which reduce DNA synthesis, aminoglycosides (neomycin, paromomycin) which ultimately slow down the protein synthesis, and imidazoles (clotrimazole, itraconazole, ketoconazole, fluconazole, miconazole) which weaken cell walls and polyenes, such as amphotericin B [28]. There are certain limitations in the treatment of Acanthamoeba infections. The main problem with this parasite is its eradication from the site of infection as under hostile conditions it encysts itself and resists various chemicals. Thus medical treatment is mostly less effective against cysts as compared to trophozoites. The rigidness of cysts is because of its double-layered wall which formulates it extremely resistant to anti-amoebic drugs and it can cause relapse of the disease [29]. Furthermore, the risk of drug resistance, expensiveness of medical treatment and its frequent adverse side effects are major restrictions.

\section{Peganum harmala, Ricinus communis and Melia azedarach}

Recently Peganum harmala, Melia azedarach, and Ricinus communis has been used in vitro to check the anti-amoebicidal activity [30]. This study described that Peganum harmala exhibited maximum amoebicidal effects followed by Ricinus communis and Melia azedarach at $1.5 \mathrm{mg} / \mathrm{ml}$. It was also shown that even after $24 \mathrm{~h}$ incubation Acanthamoeba could not damage human corneal epithelial cells (HCEC) cells layer in the existence of all extracts dilutions tested. On the other hand when amoeba was incubated with HCEC in the absence of extracts, amoeba completely destroyed the HCEC cells layer.

Acanthamoeba normally exhibits more than $90 \%$ adhesion to HCEC which was drastically reduced with all the extracts tested. Interestingly among all Peganum harmala have demonstrated the highest inhibition ( $>50 \%$ ) of amoebic adhesion to HCEC cells layer at maximum dose $1.5 \mathrm{mg} / \mathrm{ml}$. Furthermore studies have shown that Acanthamoeba produces maximum HCEC cell death (> $80 \%$ ) within $24 \mathrm{~h}$ which was drastically inhibited in the presence of plant extracts at maximum dose tested $(1.5 \mathrm{mg} /$ $\mathrm{ml}$ ). This was further supported by haematoxylin staining which demonstrated that all plants extracts safeguard the HCEC cells layer from amoeba, while the Acanthamoeba alone without extracts with HCEC destroy the whole cell layer. 
Another interesting finding of the study was that Acanthamoeba could not multiply in number when incubated with extracts even after a week time suggesting crude extracts reduces Acanthamoeba number raise. On the other hand Acanthamoeba displayed maximum growth in growth medium without HCEC cells.

\section{Allium sativum}

This study [31] for the first time described the activity of non-polar methanolic extracts of Allium Sativum on the proliferation of Acanthamoeba castelanii cysts and trophozoites at various doses (ranging from 0.78 to $62.50 \mathrm{mg} / \mathrm{mL}$ ) for different time intervals. This study further elaborates that due to presence of extract after first hour all the trophozoites were killed with $62.50 \mathrm{mg} / \mathrm{mL}$ dose while the trophozoites were viable at lower concentration 0.78 to $31.25 \mathrm{mg} / \mathrm{mL}$ for some time and disappeared after $72 \mathrm{~h}$. On the other hand extracts could not show significant effect on Acanthamoeba cysts after 3 hours which demonstrated the strong resistance of the cyst to chemicals as compare to the trophozoite. After 6 hours, the only dose showed cyst inhibition was $62.40 \mathrm{mg} / \mathrm{mL}$ while low doses $0.78-1.95 \mathrm{mg} /$ $\mathrm{mL}$ had no effect even after $72 \mathrm{~h}$. Cytotoxic effects to corneal cells were also evaluated in the presence of difference concentration of extact. It was reported the extract showed cytotoxic inhibition with dose dependent manner with maximum activity on maximum concentration. Thus, Acanthamoeba trophozoites are more sensitive to A. sativum extracts than cysts. A. scrodoprosum subsp. rotundum exhibited outstanding amoebicidal effect on Acanthamoeba and might be used as a new natural agent against Acanthamoeba.

\section{Origanum syriacum and Origanum laevigatum}

Two species of genus Origanum Syriacum and Origanum Laevigatum have been tested for amoebicidal activity on both cysts and trophozoites [32]. Different doses of methanolic extracts ( 1 to $32 \mathrm{mg} / \mathrm{ml}$ ) have been used to evaluate the activity with exponential increase in the time period. Effectiveness of Origanum laevigatum has been reported to be less than that of Origanum Syriacum. Within 3h, extract of O. Syriacum with $32 \mathrm{mg} / \mathrm{mL}$ dose has been proved to be effective against trophozoites only. After $72 \mathrm{~h}$ trophozoites have been inhibited with 32 and $16 \mathrm{mg} / \mathrm{ml}$ only. On the other hand the cyst showed significant resistance at different time intervals except the high dose $(32 \mathrm{mg} / \mathrm{mL})$ which ultimately killed cysts while no inhibition was observed with other doses. Origanum Syriacum has very less effect on cysts of Acanthamoeba which shows the resistance of cysts against this herb.

\section{Curcuma longa L., Arachis hypogaea L. and Pancratium maritimum $L$}

Curcuma longa L: Antiparasitic activity of Curcuma longa has also been studied against various parasites like Schistosoma, Leishmania, Plasmodium, Trypanosoma and more usually against other cosmopolitan parasites like Babesia, Coccidia, nematodes, Giardia and Sarcoptes [33]. One of the recent study conducted by El-Sayed et al. [28] showed an inhibitory effect of $C$. longa $L$ on Acanthamoba castellanii cyst increase with MIC of $1 \mathrm{~g}$ and $100 \mathrm{mg} / \mathrm{ml}$ after 48 and $72 \mathrm{~h}$, respectively. Concentration of $10 \mathrm{mg} / \mathrm{ml}$ extract failed to cause entire blockage of Acanthamoeba castellanii cyst growth. After $72 \mathrm{~h}, 90.2 \%$ of maximal inhibition has been observed while $1 \mathrm{mg} / \mathrm{ml}$ and $0.1 \mathrm{mg} / \mathrm{ml}$ doses demonstrated growth decrease by $60-83.1 \%$ in all times intervals tested. These findings have been recognized to the curcumin which is the main component responsible for its biological activities. In previous studies [34] it has been described as anti-malarial agent by showing its cytotoxic effect on mitochondrial and nuclear DNA of (P. falciparum).

Arachis hypogaea L: In a study conducted by [28] a notable inhibitory effect was observed on Acanthamoeba castellanii cysts with the ethanol extract of $A$. hypogaea $L$. The dodes 0.1 and $0.01 \mathrm{mg} / \mathrm{ml}$ exhibited growth decline by $64.4 \%-82.6 \%$ in all incubation periods while more inhibition was observed with MIC of 1,10 and $100 \mathrm{mg} / \mathrm{ml}$ after 24, 48, and $72 \mathrm{~h}$, respectively. These findings have been recognized to quercetin and flavonoids which characterize a key component responsible for its natural actions. One more biologically active compound flavonoid has been identified as anti-leishmania activity [35]. Quercetin in this plant has been reported as an inhibitor of DNA production and detained cell cycle progression in Leishmania donovani promastigotes, which ultimately lead to apoptosis [36].

Pancratium maritimum L: This plant contain metabolite like Pancratistatin which has a wide range of therapeutic benefits such as anti-viral, anti-neoplastic and antiparasitic effect against Encephalitozoon intestinalis [37,38]. The main active compounds alkaloids, phenolic acids and flavonoids in this plant are well known for their anti-malarial, anti-fungal and cytotoxic properties [39-42].

Efficacy of $P$. maritimum against $A$. castellanii cyst growth was observed by El-Sayed et al. [28]. This study reveled that MIC of $200 \mathrm{mg} / \mathrm{ml}$ after $72 \mathrm{~h}$ affects the growth while the 20 and $2 \mathrm{mg} / \mathrm{ml}$ doses exhibited optimal growth decrease by $94.3 \%$ and $85.5 \%$, respectively with in $72 \mathrm{~h}$. However, the lower doses of 0.2 and $0.02 \mathrm{mg} / \mathrm{ml}$ demonstrated growth decrease by 34-74.8 in all time intervals. The findings in the study have been attributed to pancratistatin and 7-deoxynarciclasine which are cyclin kinase inhibitors as cyclin-dependent kinase and their controllors are well known for their contribution in the reproduction and expansion of the eukaryotes. Thus, these enzymes characterize striking possible targets for anti-parasitic chemotherapy [37]. Moreover, cytotoxic phenolic composites like flavonoids and phenolic acids have also been attributed to this anti-parasitic activity.

\section{Croton}

Anti-amoebic activity against Acanthamoeba polyphaga (ATCC 30461) of three species that is Croton Pallidulua, Croton Ericoides, and Croton Isabelli activity and cytotoxic effect in mammalian cells has been studied by [43]. 
Croton Isabelli: The oil of C. isabelli has shown low amoebicidal activity. The dose of $10 \mathrm{mg} / \mathrm{ml}$ could only killed $4 \%$ of the Acanthamoeba polyphaga trophozoites. Very low action was recorded for the oil of $\mathrm{C}$. isabelli, in which no monoterpenes were found. It has also been shown that oils of $\mathrm{C}$. isabelli were lethal to $98 \%$ when tested against Vero cell line [43].

Croton pallidulus: The oils of $C$. pallidulus in the final doses of $2.5,5$, and $10 \mathrm{mg} / \mathrm{ml}$ have been identified as trophozoiticidal. These oils showed only $29 \%$ inhibition of trophozoites with $0.5 \mathrm{mg} / \mathrm{mL}$ concentration. These oils could not show hydrocarbon monoterpenes but $16.2 \%$ of oxygenated monoterpenes that perhaps contributed for the recorded activity. It has also been observed that the oils of C. pallidulus were toxic up to $98 \%$ against Vero cell line [43].

Croton ericoides: Trophozoites have been killed by C. ericoides essential oils with doses $2.5,5$, and $10 \mathrm{mg} / \mathrm{ml}$. These extracted oils are extra active and ableed to kill $87 \%$ of trophozoites at the dose of $0.5 \mathrm{mg} / \mathrm{ml}$. The greater activity of $C$. ericoides perhaps due to improved percentage of monoterpenes, composites with known organic characteristics. C. ericoides exhibited the optimal cytotoxicity being to disrupt $100 \%$ of the Vero cell line, and after the experiment no active/live cells were observed [43].

\section{Pterocaulon}

Pterocaulum polystachyum: In a study conducted by [44], the extract of Pterocaulum polystachyum taken in hexane demonstrated amoebicidal property against a virulent strain of Acanthamoeba (50492). When the amoebicidal activity of extract of $P$. polystachyum and extracts of dichloromethane, hexane and methanol fractions at the dose of $5 \mathrm{mg} / \mathrm{ml}$ were analysed, all the doses exhibited additional activity than the crude methanolic extract. It was also observed that, among all fractions, the increase in the activity was directly proportional to the lipophilic character of the sample. The activity of fraction obtained from hexane was dose dependent and after 48 and $72 \mathrm{~h}$ almost 66-69\% trophozoites were killed with this fraction. Along with the inhibition of trophozoites, this fraction also prevented the encystment of the trophozoites. Ergosterol is the major component of the outer walls of majority of the fungi and thus the procedure of action of the antifungal agents is totally based on the relation or on the inhibition of it [45]. Some drugs like amphotericin B (Polyenic derivative) and fluconazole (azoles) are used as anti-protozoals for their stimulation on the cell membrane. Hence, the excisting of ergosterol and other sterols in the Acanthamoeba's membrane might explain the sensitivity of these amoebas to these drugs. So, it is assumed that, coumarins presence in the fraction obtained by hexane treatment could interrelate with the ergosterol of the Acanthamoeba's membrane. Furthermore, it has also been reported that, compounds of this reduce few enzymes involved in the synthesis of sterol [46].

In a study conducted by [47] P. polystachyum demonstrated that amoebicidal action against trophozoites of a virulent strain of Acanthamoeba polyphaga (ATCC 30461). With 5, 2.5 and $1.25 \mathrm{mg} / \mathrm{ml}$, the extracted oil was capable of killing $81.1 \%$, $71.6 \%$ and $60 \%$ of the trophozoites, respectively. Within $24 \mathrm{~h}$, the inhibition of trophozoites has been observed with the doses of 20 and $10 \mathrm{mg} / \mathrm{ml}$. Laboratory tests have also showed the inhibition of all trophozoites with the doses of 20 and 10mg/ $\mathrm{ml}$, while with $5,2.5$ and $1.25 \mathrm{mg} / \mathrm{ml}$, the oil killed $80.7 \%, 46.3 \%$ and $46 \%$ trophozoites, respectively. This activity is directly proportional to the increase of the dose. This oil also prevents encystment of the trophozoites. When this oil was subjected to cytotoxic test it showed high cytotoxicity against Vero cells. However, its contribution for the inhibition of trophozoites and prevention of encystment can't be neglected so this oil can be utilized in contact lens cleaning solutions after the elimination of its hazardous effects on mammalian cells.

\section{Saliva staminae and Salvia caespitose}

Salvia staminae: Goze and co worker in 2009 [48] tested different doses of methanolic extract of S. staminea was tested against both Acanthamoeba castellanii trophozoites and cysts. Different doses from $1-32 \mathrm{mg} / \mathrm{ml}$ were prepared to test their effect along with an increase in the time period. After 6 hours, no active/live trophozoites were seen with $32 \mathrm{mg} / \mathrm{mL}$ concentration. All the trophozoites were inhibited by all doses after 72 hours. When cysts were observed after 6 hours, there was a decrease in number of cysts but complete inhibition was observed after 12 hours. After 72 hours, doses with concentration 32, 16 and $8 \mathrm{mg} / \mathrm{ml}$ killed all the cysts. There is an increase in number of trophozoites and cysts with the decrease in concentrations of the extracts.

Salvia caespitose: Complete inhibition of trophozoites was observed after $12 \mathrm{~h}$ with $32 \mathrm{mg} / \mathrm{ml}$ concentration. After $24-48$ hours, two doses i.e. 16 and $32 \mathrm{mg} / \mathrm{ml}$ inhibited the trophozoites completely. When results were observed after $72 \mathrm{~h}$, three doses i.e. 8,16 and $32 \mathrm{mg} / \mathrm{ml}$ showed an inhibition. Resistance of cysts can be estimated by analyzing the observed data in which complete inhibition was observed with $32 \mathrm{mg} / \mathrm{ml}$ concentration after $48 \mathrm{~h}$ and after $72 \mathrm{~h}$, two doses 16 and $32 \mathrm{mg} / \mathrm{ml}$ showed the same results.

S. staminea extracts obtained by methanolic treatment have shown no cell death at the dose of $16 \mathrm{mg} / \mathrm{ml}$. But non-cytotoxic effects were observed at $32 \mathrm{mg} / \mathrm{ml}$ for $S$. caespitosa extracts obtained by methanolic treatment. No decolonization zone was observed around the samples. Even though the Acanthamoeba were in direct contact with the Salvia species extracts obtained by methanolic treatment in the growth medium, there were no signs of damage to their morphological properties and seemed similar to controls trails.

\section{Pouzolzia indica and virkon®}

Pouzolzia indica: In an investigation conducted by [49] light, scanning and electron microscopic studies were performed to check the activity of methanolic extract Pouzolzia indica 
on Acanthamoeba cysts. Six dilutions were used to check the amoebicidal activity. After treating with minimum concentration of 1:4, light micrographs of cysts showed the double walls of cyst with crumple ectocyst and even endocyst. The space between the endocyst and cell membrane increased due to cutering of inside cell. Organelles were difficult to identify and few cells got excluded as many unfilled cells could be recognized. When cysts were observed under a transmission electron microscope, it showed the deterioration of the cyst walls, become visible as the exposed electron dense myelin-like structure which surrounds the cytoplasm. Within the cytoplasm appeared as clumps, with the anonymous plasma membrane. Various micrographs showed an unfilled and rip open cyst wall due to expulsion of the cytoplasm to the environment. A series of deterioration of cyst's morphology was observed under scanning electron microscope. Firstly, the oval cysts became flat and ectocyst walls collapsed after shrinkage. In some cyst, dropsical appearance was observed due to damaged opercula. After the entrance of fluid inside the cyst wall the dropsical cyst wall torn into pieces [49]. It has been reported that there is a great amount of phenolic and sugar substances in extracted Pouzolzia indica Benn. Phenolic compounds injure the plasma membrane which resulted into the leakage of intracellular components of the cell. Phenolic compounds perform as oxidizing agents which, cause cell membrane injury by responding with cellular carbohydrates, lipids, proteins and nucleic acids [50-53].

Virkon: Roongruangchai and co-workers in 2010 [54] compared the activity of methanolic extracts of Pouzolzia indica and Virkon against Acanthamoeba cysts. Cysts treated with both showed same morphological changes like cytoplasmic clumps, unfilled double walled cysts and injured cyst walls under a light microscope. Transmission electron microscope showed the exposed and broke cyst walls along with injured cytoplasmic organelles. Shrinkage and destruction of the cytoplasmic machinery inside the cyst wall occurred. Scanning electron micrographs (SEM) exposed crushed crumpled strips with inflamed and integrated cyst walls. Virkon activity is due to the presence of an active ingredient i.e. potassium peroxymonosulphate. Virkon is a tough oxidizing agent and having a highest surfactant which responds with some proteins of the cell cytoplasm or cell wall $[55,56]$.

This study concludes the destruction of cyst in a three step process as, firstly, the cyst walls contract the opercula are damaged and the cyst wall divides, along with cytoplasmic clusters and eject out of the cyst wall. In a second step, the cysts become dropsical due to passing of the solution into the cell, causing decreased wrinkling of the cyst wall. In the last step, the cyst walls tear and break into small pieces.

\section{Cananga odorata, Kaempferia galangal and Ipomoea sp.}

Chu and co-workers in 1998 [57] selected plants from Southeast Asia to check amoebicidal activity. Amoebae cultured in plant extract were investigated for encystment or lysis. Two hundred plant extracts were examined during this study. The extracts acquired from three plants Cananga odorata, Kaempferia galangal and Ipomoea sp., were discovered to have amebicidal activity against 3 species of Acanthamoeba in vitro, whereas a $4^{\text {th }}$ extract obtained from Gastrochilus panduratum showed amebicidal activity against Acanthamoeba polyphaga but not against Acanthamoeba castellanii or Acanthamoeba culbertsoni. Some of the plant extracts also exhibited tumoricidal activity but did not injure the primary macrophage cultures. Natural composites obtained from plant extracts could provide as a new foundation of anti-amoebic drugs for the treatment of amoebic keratitis, carcinomas and GAE.

\section{Peucedanum species}

Methanolic extracts of Peucedanum caucasicum, Peucedanum chryseum, Peucedanum longibracteolatum and Peucedanum palimbioides were used to investigate the amoebicidal activity in vitro by [58]. Dose ranged from 1 to $32 \mathrm{mg} / \mathrm{ml}$ was checked for 72 hours. P. longibracteolatum have shown the strongest amoebicidal effect on both trophozoites and cysts. While at maximum dose of extract $(32 \mathrm{mg} / \mathrm{ml})$ no alive Acanthamoeba trophozoites or cysts were found from 24 to $72 \mathrm{~h}$. The same results were obtained from $16 \mathrm{mg} / \mathrm{ml}$ dose of extract on trophozoites. The amount of live cysts was numbered as $10.6 \pm 2.1$ with the same concentration within 24 hour. While in the existence of extract dose $(8 \mathrm{mg} / \mathrm{ml})$, no live trophozoites were observed after 48 hour. Furthermore, at the same dose cysts (51\%) were destroyed by the extract after $72 \mathrm{~h}$. It was observed cysts showed more resistant to the extracts as compared to trophozoites.

\section{Inula oculus-christi and Pastinaca armenea}

In another study conducted in Turkey, by [59] Inula oculuschristi and Pastinaca armenea were used in vitro to estimate the amoebicidal potential of their aqueous extracts. The numbers of the live Acanthamoeba cysts and trophozoites were reduced with doses ranged from 1 to $32 \mathrm{mg} / \mathrm{ml}$. The study further elaborates that Inula oculus-christi exhibited strongest amoebicidal effect on both cysts and trophozoites. When $32 \mathrm{mg} / \mathrm{ml}$ extract dose was incubated within culture media, no live trophozoites were observed within $24 \mathrm{~h}$. Besides, when $16 \mathrm{mg} / \mathrm{ml}$ dose of Inula oculus-christi extract were used, no live trophozoites were found after $72 \mathrm{~h}$. While a restricted effects of Inula oculus-christi extract was observed on cysts. On the other hand at $32 \mathrm{mg} / \mathrm{ml}$ extract dose, only $25.3 \%$ of the total cysts were destroyed successfully. While, in the presence of $32 \mathrm{mg} / \mathrm{ml}$ extract of Pastinaca armenea, $23 \%$ cysts and $40.3 \%$ trophozoites were destroyed after $72 \mathrm{~h}$ time interval.

\section{Satureja cuneifolia and Melissa officinalis}

Methanolic extracts of Melissa officinalis and Satureja cuneifolia were used to investigate in vitro amoebicidal activity [60]. When methanolic extracts (ranging from 1 to $32 \mathrm{mg} / \mathrm{ml}$ ) were used the numbers of the viable Acanthamoeba cysts and trophozoites were reduced. Amoebicidal action was time and dose dependent. Among two extracts trails Satureja cuneifolia exhibited the optimal amoebicidal effect on both cysts and 
trophozoites. After $24 \mathrm{~h}$, in the presence of $32 \mathrm{mg} / \mathrm{ml}$ extract no live trophozoites were found. While at the same dose, the extract showed effecacy against the cysts at a rate of $46.3 \%$ after $72 \mathrm{~h}$. On the other hand Melissa officinalis exhibited restricted amoebicidal effect on Acanthamoeba. The extract dose $(32 \mathrm{mg} / \mathrm{ml})$ has shown $44.3 \%$ trophozoites and $30 \%$ cysts were destroyed.

\section{Teucrium chamaedrys and Teucrium polium}

Methanolic extracts of Teucrium chamaedrys and Teucrium polium were used [61] to investigate amoebicidal activity. Both extracts (from 1 to $32 \mathrm{mg} / \mathrm{ml}$ ) demonstrated amoebicidal potential on both cysts and trophozoites of Acanthamoeba by time and dose dependent manner. Teucrium chamaedrys demonstrated the optimal amoebicidal effect on the trophozoites. At $16 \mathrm{mg} / \mathrm{ml}$ extract concentration no live trophozoites were found after $48 \mathrm{~h}$. Similarly at $32 \mathrm{mg} / \mathrm{ml}$ extract concentration no live trophozoites were found in the case of Teucrium polium. As usual cysts were found more resistant than trophozoites at $48 \mathrm{~h}$.

\section{Pueraria lobata, Rubus chamaemorus, Solidago graminifolia and Solidago virgaurea}

This study was conducted by Derda and co-workers in 2009 [62] to investigate the amoebicidal or amoebistatic activity of potential of extracts obtained from Pueraria lobata, Rubus chamaemorus, Solidago graminifolia and Solidago virgaurea. It was found that extracts from Pueraria lobata, Rubus chamaemorus, and Solidago virgaurea exhibited chemotherapeutic characteristics in doses of about 0.01 $0.05 \mathrm{mg}$ extract $/ \mathrm{ml}$ in vitro. Furthermore at doses of $0.35 \mu \mathrm{g} / \mathrm{ml}$ expressed in ellagic acid for Rubus chamaemorus and $0.053 \mu \mathrm{g} /$ $\mathrm{ml}$ expressed in puerarin for Pueraria lobata. Therefore in vivo trails, it was also observed that, following therapy using the above mentioned extracts, trail animals infected with Acanthamoeba sp. were survived for some extra time i.e., 2.5-3 times longer. It was also assessed that extracts obtained from the selected plants could be used both internally and externally especially in a combined therapy for acanthamoebiasis. It is noteworthy that the plant extracts tested during this study was found to be non toxic to animals.

\section{Conclusion}

There is a need to develop therapies with low cost, greater efficacy and minor side effects. In this context, in the past few years the trend has been shifted towards the use of medicinal plants against Acanthamoeba (Table 2). Acanthamoeba is widely spread in air, water and soil etc this is because of their adoptable characteristics in natural environment. Furthermore Acanthamoeba has been reported to be cultured comparatively easier in laboratory conditions as compared to Balamuthia and Naegleria which could be one of the reasons of the researcher choice for folk plants extract for in vitro trails. Although this is not a new concept as plant extracts were believed to be significant for diverse ailments by the early civilizations [63]. Many natural products have been identified as antiparasitic agents with astonishing efficacy and selectivity such as plantderived terpenes, alkaloids and phenolics [64]. In developing countries, the utilization of medicinal plants by people is very popular because these products are safe, easily accessible and commonly available at low cost. In conventional medicine, the use of plants in the form of their various parts crude extracts, plasters or infusions is an extensively practiced to cure common infections in various parts of the country. In spite of this, there is still a shortage of scientific studies authenticate the possible antibiotic potential of a great number of these therapies. The plants reported in literature used against Acanthamoeba are given below in detail [28-62].

Table 2: Summary of potential folk plants used against free living amoeba.

\begin{tabular}{|c|c|c|c|c|c|c|c|c|c|c|}
\hline \multicolumn{11}{|c|}{ Different Plant Parts Used Against the Following Different Acanthamoeba Parameters } \\
\hline \multirow[b]{2}{*}{$\begin{array}{l}\text { S. } \\
\text { No }\end{array}$} & \multirow[b]{2}{*}{ Plant name } & \multirow[b]{2}{*}{ Family } & \multirow[b]{2}{*}{$\begin{array}{l}\text { Parts } \\
\text { used }\end{array}$} & \multicolumn{2}{|c|}{$\begin{array}{c}\text { Amoebicidal } \\
\text { effects }\end{array}$} & \multirow{2}{*}{$\begin{array}{c}\text { Amo } \\
\text { eba } \\
- \\
\text { med } \\
\text { iate } \\
\text { d Cyto } \\
\text { toxi } \\
\text { city }\end{array}$} & \multirow{2}{*}{$\begin{array}{c}\text { Amoe } \\
\text { b ista } \\
\text { tic } \\
\text { effe } \\
\text { cts }\end{array}$} & \multirow{2}{*}{$\begin{array}{l}\text { Amo } \\
\text { eb } \\
\text { ic Gr } \\
\text { owth }\end{array}$} & \multirow{2}{*}{$\begin{array}{c}\text { Amo } \\
\text { ebic } \\
\text { Adhe } \\
\text { sion }\end{array}$} & \multirow[b]{2}{*}{$\begin{array}{c}\text { Refer } \\
\text { ence }\end{array}$} \\
\hline & & & & $\begin{array}{c}\text { Trop } \\
\text { ho } \\
\text { zoi } \\
\text { tes }\end{array}$ & $\begin{array}{l}\text { Cy } \\
\text { sts }\end{array}$ & & & & & \\
\hline 1 & $\begin{array}{l}\text { Allium } \\
\text { sativum }\end{array}$ & $\begin{array}{c}\text { Amarylli } \\
\text { daceae }\end{array}$ & Bulb & + & + & + & - & - & - & $\begin{array}{l}\text { Polat } \\
\text { et al. } \\
\text { [31] }\end{array}$ \\
\hline 2 & $\begin{array}{l}\text { Origanum } \\
\text { syriacum }\end{array}$ & $\begin{array}{l}\text { Lamia } \\
\text { ceae }\end{array}$ & Leaves & + & + & + & - & - & - & \multirow{2}{*}{$\begin{array}{c}\text { Degerli } \\
\text { et al. } \\
{[32]}\end{array}$} \\
\hline 3 & $\begin{array}{l}\text { Origanum } \\
\text { laevigatum }\end{array}$ & $\begin{array}{l}\text { Lamia } \\
\text { ceae }\end{array}$ & Leaves & + & + & + & - & - & - & \\
\hline 4 & $\begin{array}{c}\text { Arachis } \\
\text { hypogaea L. }\end{array}$ & $\begin{array}{l}\text { Faba } \\
\text { ceae }\end{array}$ & $\begin{array}{l}\text { Shell } \\
\text { (pod) }\end{array}$ & - & + & - & - & - & - & \multirow{3}{*}{$\begin{array}{c}\text { El- } \\
\text { Sayed } \\
\text { et al. } \\
{[28]}\end{array}$} \\
\hline 5 & $\begin{array}{c}\text { Curcuma } \\
\text { longa L. }\end{array}$ & $\begin{array}{l}\text { Zingibe } \\
\text { raceae }\end{array}$ & Rhizome & - & + & - & - & - & - & \\
\hline 6 & $\begin{array}{l}\text { Pancratium } \\
\text { maritimum L. }\end{array}$ & $\begin{array}{l}\text { Amaryll } \\
\text { idaceae }\end{array}$ & Bulb & - & + & - & - & - & - & \\
\hline
\end{tabular}


International Journal of Cell Science \& Molecular Biology

\begin{tabular}{|c|c|c|c|c|c|c|c|c|c|c|}
\hline 7 & $\begin{array}{c}\text { Croton } \\
\text { pallidulua }\end{array}$ & $\begin{array}{l}\text { Euphor } \\
\text { biaceae }\end{array}$ & $\begin{array}{c}\text { Aerial } \\
\text { parts }\end{array}$ & + & - & + & & - & - & \multirow{3}{*}{$\begin{array}{l}\text { Vunda } \\
\text { et al. } \\
\text { [43] }\end{array}$} \\
\hline 8 & $\begin{array}{l}\text { Croton } \\
\text { ericoides }\end{array}$ & $\begin{array}{l}\text { Euphor } \\
\text { biaceae }\end{array}$ & $\begin{array}{l}\text { Aerial } \\
\text { parts }\end{array}$ & + & - & + & - & - & - & \\
\hline 9 & $\begin{array}{l}\text { Croton } \\
\text { isabelli }\end{array}$ & $\begin{array}{l}\text { Euphor } \\
\text { biaceae }\end{array}$ & $\begin{array}{l}\text { Aerial } \\
\text { parts }\end{array}$ & + & - & + & - & - & - & \\
\hline 10 & $\begin{array}{l}\text { Pterocaulon } \\
\text { polystachyum }\end{array}$ & $\begin{array}{l}\text { Astera } \\
\text { ceae }\end{array}$ & $\begin{array}{l}\text { Aerial } \\
\text { parts, } \\
\text { Leaves }\end{array}$ & + & - & - & - & - & - & $\begin{array}{c}\text { Rodio } \\
\text { et } \\
\text { al.[44]; } \\
\text { Sauter } \\
\text { et al. } \\
\text { [47] }\end{array}$ \\
\hline 11 & $\begin{array}{c}\text { Saliva } \\
\text { staminae }\end{array}$ & $\begin{array}{l}\text { Lamia } \\
\text { ceae }\end{array}$ & Leaves & + & + & + & - & - & - & \multirow{2}{*}{$\begin{array}{l}\text { Goze et } \\
\text { al. [48] }\end{array}$} \\
\hline 12 & $\begin{array}{c}\text { Salvia } \\
\text { caespitose }\end{array}$ & $\begin{array}{l}\text { Lamia } \\
\text { ceae }\end{array}$ & Leaves & + & + & + & - & - & - & \\
\hline 13 & $\begin{array}{l}\text { Peganum } \\
\text { harmala }\end{array}$ & $\begin{array}{l}\text { Zygoph } \\
\text { yllaceae }\end{array}$ & Seeds & + & - & + & + & + & + & \multirow{3}{*}{$\begin{array}{c}\text { Shoaib } \\
\text { et al. } \\
{[30]}\end{array}$} \\
\hline 14 & $\begin{array}{c}\text { Melia } \\
\text { azedarach }\end{array}$ & $\begin{array}{l}\text { Melia } \\
\text { ceae }\end{array}$ & Leaves & + & - & + & + & + & + & \\
\hline 15 & $\begin{array}{l}\text { Ricinus } \\
\text { communis }\end{array}$ & $\begin{array}{l}\text { Euphorb } \\
\text { iaceae }\end{array}$ & Leaves & + & - & + & + & + & + & \\
\hline 16 & $\begin{array}{c}\text { Pastinaca } \\
\text { armenea }\end{array}$ & $\begin{array}{l}\text { Apia } \\
\text { ceae }\end{array}$ & Leaves & + & + & - & - & - & - & \multirow{2}{*}{$\begin{array}{c}\text { Degerl } \\
\text { et al. } \\
{[58]}\end{array}$} \\
\hline 17 & $\begin{array}{l}\text { Inula oculus- } \\
\text { christi }\end{array}$ & $\begin{array}{l}\text { Astera } \\
\text { ceae }\end{array}$ & $\begin{array}{l}\text { Leaves, } \\
\text { seeds }\end{array}$ & + & + & - & - & - & - & \\
\hline 18 & $\begin{array}{l}\text { Pouzolzia } \\
\text { indica }\end{array}$ & $\begin{array}{l}\text { Urtica } \\
\text { ceae }\end{array}$ & $\begin{array}{l}\text { Stems, } \\
\text { leaves }\end{array}$ & - & + & - & - & - & - & $\begin{array}{c}\text { Roon } \\
\text { gruan } \\
\text { gchaiet } \\
\text { al.[49]; } \\
\text { Roon } \\
\text { gruan } \\
\text { gchaiet } \\
\text { al.[54]; }\end{array}$ \\
\hline \multirow{2}{*}{19} & \multirow{2}{*}{$\begin{array}{l}\text { Rubus } \\
\text { chamae } \\
\text { morus }\end{array}$} & \multirow{2}{*}{$\begin{array}{l}\text { Rosa } \\
\text { ceae }\end{array}$} & Flowers, & \multirow[b]{2}{*}{+} & \multirow[b]{2}{*}{ - } & \multirow[b]{2}{*}{-} & \multirow[b]{2}{*}{+} & \multirow[b]{2}{*}{ - } & \multirow[b]{2}{*}{ - } & \multirow{8}{*}{$\begin{array}{l}\text { Derda } \\
\text { et al. } \\
\text { [62] }\end{array}$} \\
\hline & & & $\begin{array}{l}\text { Roots, } \\
\text { Leaves }\end{array}$ & & & & & & & \\
\hline & Puraria & Fab? & Flowers, & & & & & & & \\
\hline 20 & lobata & ceae & $\begin{array}{l}\text { Roots, } \\
\text { Leaves }\end{array}$ & + & - & - & + & - & - & \\
\hline \multirow{2}{*}{21} & \multirow{2}{*}{$\begin{array}{l}\text { Solidago } \\
\text { virgaurea }\end{array}$} & \multirow{2}{*}{$\begin{array}{l}\text { Astera } \\
\text { ceae }\end{array}$} & Flowers, & \multirow[b]{2}{*}{+} & \multirow[b]{2}{*}{ - } & \multirow[b]{2}{*}{-} & \multirow[b]{2}{*}{+} & \multirow[b]{2}{*}{ - } & \multirow[b]{2}{*}{-} & \\
\hline & & & $\begin{array}{l}\text { Roots, } \\
\text { Leaves }\end{array}$ & & & & & & & \\
\hline \multirow[b]{2}{*}{22} & \multirow{2}{*}{$\begin{array}{c}\text { Solidago } \\
\text { graminifolia }\end{array}$} & \multirow{2}{*}{$\begin{array}{l}\text { Astera } \\
\text { ceae }\end{array}$} & Flowers, & \multirow[b]{2}{*}{+} & \multirow[b]{2}{*}{-} & \multirow[b]{2}{*}{-} & \multirow[b]{2}{*}{+} & \multirow[b]{2}{*}{-} & \multirow[b]{2}{*}{-} & \\
\hline & & & $\begin{array}{l}\text { Roots, } \\
\text { Leaves }\end{array}$ & & & & & & & \\
\hline 23 & Ipomoea sp. & $\begin{array}{l}\text { Convolvu } \\
\text { laceae }\end{array}$ & $\begin{array}{l}\text { Leaves, } \\
\text { flowers, } \\
\text { roots, } \\
\text { bark }\end{array}$ & + & - & - & - & - & - & \\
\hline 24 & $\begin{array}{l}\text { Kaempferia } \\
\text { galanga }\end{array}$ & $\begin{array}{l}\text { Zingiber } \\
\text { aceae }\end{array}$ & $\begin{array}{l}\text { Leaves, } \\
\text { flowers, } \\
\text { roots, } \\
\text { bark }\end{array}$ & + & - & - & - & - & - & $\begin{array}{l}\text { Chu et } \\
\text { al. [57] }\end{array}$ \\
\hline 25 & $\begin{array}{l}\text { Cananga } \\
\text { odorata }\end{array}$ & $\begin{array}{l}\text { Annona } \\
\text { ceae }\end{array}$ & $\begin{array}{l}\text { Leaves, } \\
\text { flowers, } \\
\text { roots, } \\
\text { bark }\end{array}$ & + & - & - & - & - & - & \\
\hline
\end{tabular}




\section{International Journal of Cell Science \& Molecular Biology}

\begin{tabular}{|c|c|c|c|c|c|c|c|c|c|c|}
\hline 26 & $\begin{array}{l}\text { Peucedanum } \\
\text { caucasicum }\end{array}$ & $\begin{array}{l}\text { Apiac } \\
\text { eae }\end{array}$ & $\begin{array}{l}\text { Flower, } \\
\text { seeds }\end{array}$ & + & + & - & - & - & - & \multirow{4}{*}{$\begin{array}{c}\text { Mal } \\
\text { atyali } \\
\text { et al. } \\
{[59]}\end{array}$} \\
\hline 27 & $\begin{array}{l}\text { Peucedanum } \\
\text { longibracte } \\
\text { olatum }\end{array}$ & $\begin{array}{l}\text { Apia } \\
\text { ceae }\end{array}$ & $\begin{array}{l}\text { Flower, } \\
\text { seeds }\end{array}$ & + & + & - & - & - & - & \\
\hline 28 & $\begin{array}{c}\text { Peucedanum } \\
\text { chryseum, }\end{array}$ & $\begin{array}{l}\text { Apia } \\
\text { ceae }\end{array}$ & $\begin{array}{l}\text { Flower, } \\
\text { seeds }\end{array}$ & + & + & - & - & - & - & \\
\hline 29 & $\begin{array}{l}\text { Peucedanum } \\
\text { palimb } \\
\text { ioides, }\end{array}$ & $\begin{array}{l}\text { Apia } \\
\text { ceae }\end{array}$ & $\begin{array}{l}\text { Flower, } \\
\text { seeds }\end{array}$ & + & + & - & - & - & - & \\
\hline 30 & $\begin{array}{c}\text { Satureja } \\
\text { cuneifolia }\end{array}$ & $\begin{array}{l}\text { Lamia } \\
\text { ceae }\end{array}$ & $\begin{array}{l}\text { Leaves, } \\
\text { seeds }\end{array}$ & + & + & - & - & - & - & \multirow{2}{*}{$\begin{array}{c}\text { Mal } \\
\text { atyali } \\
\text { et al. } \\
{[60]}\end{array}$} \\
\hline 31 & $\begin{array}{l}\text { Melissa } \\
\text { officinalis }\end{array}$ & $\begin{array}{l}\text { Lamia } \\
\text { ceae }\end{array}$ & $\begin{array}{l}\text { Flower, } \\
\text { leaves }\end{array}$ & + & + & - & - & - & - & \\
\hline 32 & $\begin{array}{l}\text { Teucrium } \\
\text { polium }\end{array}$ & $\begin{array}{l}\text { Lamia } \\
\text { ceae }\end{array}$ & $\begin{array}{l}\text { Flower, } \\
\text { leaves }\end{array}$ & + & + & - & - & - & - & \multirow{2}{*}{$\begin{array}{l}\text { Tepe et } \\
\text { al. [61] }\end{array}$} \\
\hline 33 & $\begin{array}{c}\text { Teucrium } \\
\text { chamaedrys }\end{array}$ & $\begin{array}{l}\text { Lamia } \\
\text { ceae }\end{array}$ & $\begin{array}{l}\text { Flower, } \\
\text { leaves }\end{array}$ & + & + & - & - & - & - & \\
\hline
\end{tabular}

For the past few years, FLA has gained much attention by scientific community because of its vast prevalence in our environment and thus causing deadly infections in humans. The main hindrance in the treatment of infections is the formation of cyst which results in the failure of treatment with chemotherapeutic agents. The life cycle of FLA consists of an infective trophozoites and cyst forms. Under harsh conditions, trophozoites differentiate into a cyst form. Cysts are double walled, consisting of an outer ectocyst and an inner endocyst. Both walls meet at points known as arms or rays. Furthermore, amoeba cysts can survive up to several years while maintaining their pathogenicity [65]. These characteristics suggest that the key functions of cysts are to withstand the adverse conditions and spreading of amoebae throughout the environment. Amoebae cysts are metabolically inactive and resistant to many chemotherapeutic drugs resulting in the recurrence of the disease. For instance, Ficker and co-workers in 1990 [66] observed the development of propamidine resistance during the course of therapy for Acanthamoeba keratitis, which led to recurrence of the infection. This is of particular concern with the availability of very limited drugs for Acanthamoeba infections. The process of encystment in Acanthamoeba is triggered under harsh environmental conditions. This is a reversible change and is dependent on the environmental conditions.

Moreover, these chemotherapeutic agents also produce side effects with lower efficacy. In this perspective, the trend has been shifted towards the use of medicinal plants which have higher efficacy and less side effects. The utilization of medicinal plants by the community in developing countries is widespread because the products achieved from these plants are widely reachable at low cost, safe and easily available. In conventional medicine, the plants utilization in the form of infusions, crude extracts or plasters is a common practice to nurse common infections in various parts of the world. In spite of this, still not much scientific reports validating the promising antibiotic potential of a vast number of these therapies. In vitro antimicrobial screening methods may provide the required initial interpretation to choose, among the crude plant products, those with possible valuable characteristics for further pharmacological and chemical studies.

However, a complete understanding of FLA pathogenesis is crucial to develop therapeutic interventions to design preventative measures. Folk plants and their products could be a potential candidate for the therapeutic drug discovery against FLA. Among all folk plants Allium sativum, Peganum harmala, Origanum syriacum, Arachis hypogaea L., Pancratium maritimum L., Pterocaulum polystachyum, Salvia caespitose, and Melissa officinalis have shown optimal anti-Acanthamoeba effects in vitro. Present review suggests the possibility of further research with purified fractions of plant extracts to identify the active ingredients and to elucidate the mechanism of action of the effective compounds both in vitro and in vivo which may provide a new series of potential chemotherapeutic agents against FLA. To the best of our knowledge, this report is the first extensive review regarding the utilization of folk plants against FLA in literature.

\section{Acknowledgment}

The authors are indebted to Dr. Suk-Yul Jung, South Korea; Ambreen Gul Muazzam, Canada; Eleni Pavlopoulou, England; Hafiz Muhammad Shohaib, Abida Akbar, Pakistan for assistance. Furthermore, we are also very thankful to Ed Jarroll, Boston, for providing us TEM images of Balamuthia mandrillaris.

\section{References}

1. Martinez AJ (1985) Free-Living Amoebas: Natural History, Prevention, Diagnosis, Pathology, and Treatment of Disease. CRC Press, Boca, Raton, Florida, USA.

2. Martinez AJ, Visvesvara GS (1997) Free-living, amphizoic and opportunistic Brain Pathol amebas. 7(1): 583-598.

3. Visvesvara GS, Maguire JH (2006) Pathogenic and opportunistic free-living amebas. In: Guerrant RL, et al. (Eds.), Acanthamoeba spp, Balamuthia mandrillaris, Naegleria fowleri and Sappinia diploidea. Tro Infec Dis 2: 1114-1125. 
4. Castellani A (1930) An amoeba found in culture of yeast: preliminary note. Trop Med Hyg 33: 160.

5. Douglas M (1930) Notes on the classification of the amoeba found by Castellani on culture of a yeast-like fungus. Trop Med Hyg 33: 258-259.

6. Volkonsky M (1931) Hartmanella castellanii Douglas, et classification des hartmannelles. Arch Zool Exp Gen 72: 317-339.

7. Marciano-CF, Cabral G (2003) Acanthamoeba spp. as agents of disease in humans. Clin Microbiol Rev 16(2): 273-307.

8. Martinez AJ, Janitschke K (1985) Acanthamoeba, an opportunistic microorganism: a review. Infection 13(6): 251-256.

9. Anzil AP, Chandrakant R, Wrzolek MA, Visvesvara GS, Sherand JH, et al (1991). Amebic meningoencephalitis in a patient with AIDS caused by a newly recognized opportunistic pathogen. Arch Pathol Lab Med 115(1): 21-25.

10. Taratuto AL, Monges J, Acefe JC, Meli F, Paredes A (1991) Leptomyxid amoeba encephalitis: report of the first case in Argentina. Trans R Soc Trop Med Hyg 85(1): 77.

11. Visvesvara GS, Moura H, Schuster FL (2007) Pathogenic and opportunistic free-livingamoebae: Acanthamoeba spp, Balamuthia mandrillaris, Naegleria fowleri and Sappinia diploidea. FEMS Immunol Med Microbiol 50(1): 1-26.

12. Healy JF (2002) Balamuthia amebic encephalitis: radiographic and pathologic findings. Am J Neuro 23(3): 486-489.

13. Deetz TR, Sawyer MH, Billman G, Schuster FL, Visvesvara GS (2003) Successful treatment of Balamuthia amoebic encephalitis: presentation of 2 cases. Clin Infect Dis 37(10): 1304-1312.

14. Matin A, Siddiqui R, Jayasekera S, Khan NA (2008) The increasing importance of Balamuthia mandrillaris. Clin Microbiol Rev 21(3): 435448.

15. Bakardjiev A, Azimi PH, Ashouri N, Ascher DP, Janner D, et al (2003) Amoebic encephalitis caused by Balamuthia mandrillaris: report of four cases. Pediatr Infect Dis 22(5): 447-452.

16. Schuster FL, Visvesvara GS (2004) Free-living amoebae as opportunistic and non-opportunistic pathogens of humans and animals. Int Parasitol 34(9): 1001-1027.

17. Marciano-CF (1988) Biology of Naegleria spp. Microbiol Rev 52(1) 114-133.

18. Rodriguez-ZS (1994) Ecology of free-living amoebae. Crit Rev Microbiol 20(3): 225-241

19. Szenasi Z, Endo T, Yagita K, Nagy E (1998) Isolation, identification, and increasing importance of 'free-living' amebae causing human disease. Med Microbiol 47(1): 5-16.

20. Fowler M, Carter RF (1965) Acute pyogenic meningitis probably due to Acanthamoeba sp: a preliminary report. Br Med J v.2: 740-742.

21. Marciano-CF, MacLean R, Mensah A, LaPat-PL (2003) Identification of Naegleria fowleri in domestic water sources by nested PCR. Appl Env Microbiol 69(10): 5864-5869.

22. Carter RF (1970) Description of a Naegleria sp. isolated from two cases of primary amoebic meningoencephalitis and of the experimental pathological changes induced by it. Pathol 22: 470-474.

23. Barnett ND, Kaplan AM, Hopkin RJ, Saubolle MA, Rudinsky MF (1996) Primary amoebic meningoencephalitis with Naegleria fowleri: clinical review. Pediatr Neurol 15(3): 230-234.

24. Tanveer T, Hameed A, Muazzam AG, Jung SY, Gul A, et al (2013) Isolation and molecular characterization of potentially pathogenic Acanthamoeba genotypes from diverse water resources including household drinking water from Khyber Pakhtunkhwa, Pakistan Parasitol Res 112 (8): 2925-2932.
25. Kitagawa K, Nakamura T, Takahashi N, Oikawa Y, Ikeda T (2003) A novel combination treatment of Chlorohexidine gluconate, natamycin (pimaricin) and debridement for a Acanthamoeba keratitis. Jap J Ophthalmol 47(6): 616-617.

26. Seal DV (2003) Acanthamoeba keratitis update-incidence, molecular epidemiology and new drugs for treatment. Eye 17(8): 893-905.

27. Murdoch D, Gray TB, Cursons R, Parr D (1998) Acanthamoeba keratitis in New Zealand, including two cases with in vitro resistance to polyhexamethylene biguanide. Australian and New Zeland Journal of Ophthalmology 26(3): 231-236.

28. El-Sayed NM, Ismail KI, Ahmed SG, Hetta MH (2012) In vitro amoebicidal activity of ethanol extracts of Arachis hypogaea L, Curcuma longa L and Pancratium maritimum L on Acanthamoeba castellanii cysts. Parasitol Res 110(5): 1985-1992.

29. Leitsch D, Köhsler M, Marchetti-DM, Deutsch A, Allmaier G, et al. (2010) Major role for cysteine proteases during the early phase of Acanthamoeba castellanii encystment. Euk Cell 9(4): 611-618.

30. Shoaib HM, Muazzam AG, Mir A, Jung SY, Matin A (2013) Evaluation of inhibitory potential of some selective methanolic plants extracts on biological characteristics of Acanthamoeba castellanii using human corneal epithelial cells in vitro. Parasitol Res 112(3): 1179-88.

31. Polat ZA, Vural A, Ozan F, Tepe B, Ozcelik S, et al. (2008) In vitro evaluation of the amoebicidal activity of garlic (Allium sativum) extract on Acanthamoeba castellanii and its cytotoxic potential on corneal cells. Ocul Pharmacol Ther 24(1): 8-14.

32. Degerli S, Tepe B, Celiksoz A, Berk S, Malatyali E (2012) In vitro amoebicidal activity of Origanum syriacum and Origanum laevigatum on Acanthamoeba castellanii cysts and trophozoites. Exp Parasitol 131(1): 20-24.

33. Haddad M, Sauvain M, Deharo E (2011) Curcuma as a parasiticidal agent: a review. Planta Med 77(6): 672-678.

34. Cui L, Miao J, Cui L (2007) Cytotoxic effect of curcumin on malaria parasite Plasmodium falciparum: inhibition of histone acetylation and generation of reactive oxygen species. Antimicrob Agents Chemother 51(2): 488-494.

35. Yazaki K, Sasaki K, Tsurumaru Y (2009) Prenylation of aromatic compounds, a key diversification of plant secondary metabolites. Phytochemistry 70(15-16): 1739-1745.

36. Koide T, Nose M, Ogihara Y, Yabu Y, Ohta N (2002) Leishmanicidal effect of curcumin in vitro. Biol Pharm Bull 25(1): 131-133.

37. Ouarzane-AM, Franetich JF, Mazier D, Pettit GR, Meijer L, et al. (2001) In vitro activities of two antimitotic compounds, pancratistatin and 7-deoxynarciclasine, against Encephalitozoon intestinalis, a microsporidium causing infections in humans. Antimicrob Agent Chemother 45(12): 3409-3415.

38. Pandey S, Kekre N, Naderi J, McNulty J (2005) Induction of apoptotic cell death specifically in rat and human cancer cells by pancratistatin. Artif Cells Blood Substit Immo Biotechnol 33(3): 279-295.

39. Kaya GI, Sarıkaya B, Çiçek D, Somer NU (2010) In vitro cytotoxic activity of Sternbergia sicula, S. lutea and Pancratium maritimum extracts. Hacet Univ J Fac Pharm 30(1): 41-48.

40. Sener B, Orhan I, Satayavivad J (2003) Antimalarial activity screening of some alkaloids and the plant extracts from Amaryllidaceae. Phytother Res 17(10): 1220-1223.

41.Sür-AD, Gürkan E, Mutlu G, Tuzlaci E, Ang Ö (1999) The antifungal activity of Pancratium maritimum. Fitoterapia 70(2): 187-189.

42. Youssef DTA, Ramadan MA, Khalifa AA (1998) Acetophenones, a chalcone, a chromone and flavonoids from Pancratium maritimum. Phytochem 49(8): 2579-2583. 
43. Vunda SL, Sauter IP, Cibulski SP, Roehe PM, Bordignon SA, et al. (2012) Chemical composition and amoebicidal activity of Croton pallidulus, Croton ericoides, and Croton isabelli (Euphorbiaceae) essential oils. Parasitol Res 111(3): 961-966.

44. Ródio C, da Rocha VD, Kowalski KP, Panatieri LF, von Poser G, et al. (2008) In vitro evaluation of the amebicidal activity of Pterocaulon polystachyum (Asteraceae) against trophozoites of Acanthamoeba castellanii. Parasitol Res 104: 191-194.

45. Odds FC, Brown AJP, Gow NAR (2003) Antifungal agents: mechanisms of action. Trends Microbiol 11(6): 272-279.

46. Cravotto G, Balliano G, Robaldo B, Oliaro-BS, Chimichi S, et al. (2004) Farnesyloxycoumarins, a new class of squalene-hopene cyclase inhibitors. Bioorg Med Chem Lett 14(8): 1931-1934.

47. Sauter IP, dos Santos JC, Apel MA, Cibulski SP, Roehe PM, et al. (2011) Amoebicidal activity and chemical composition of Pterocaulon polystachyum (Asteraceae) essential oil. Parasitol Res 109(5): 13671371.

48. Goze I, Alim A, Dag S, Tepe B, Polat ZA (2009) In vitro amoebicidal activity of Salvia staminea and Salvia caespitosa on Acanthamoeba castellanii and their cytotoxic potentials on corneal cells. Ocul Pharmacol Therapeut 25(4): 293-298.

49. Roongruangchai J, Sookkua T, Kummalue T, Roongruangchai K (2009) Pouzolzia indica methanolic extract Fraction 2 and Povidone-Iodine induced changes in the cyst of Acanthamoeba spp. light and electron microscopic studies. Med Assoc Thai 92(11): 1492-1499.

50. Trakulsomboon S, Kummalue T, Jiratchariyakul W (2006) Antibacterial activities of four Thai medicinal plants. Med Assoc Thai 89(9): 14661471.

51. Mcdonnell G, Russell AD (1999) Antiseptic and disinfectants: activity, action, and resistance. Clin Microbial Rev 12(1): 147-179.

52. Pacifici RE, Davies KJ (1991) Protein, lipid and DNA repair systems in oxidative stress; the free radical theory of aging revisited. Gerontology 37(1-3): 166-180.

53. Roufogalis BD, Li Q, Tran VH, Kable EPW, Duke CC (1999) Investigation of plant-derived phenolic compounds as plasma membrane $\mathrm{Ca} 2+$ ATPase inhibitors with potential cardiovascular activity. Drug Dev Res 46(3-4): 239-249.

54. Roongruangchai K, Kummalue T, Sookkua T, Roongruangchai J (2010) Comparison of Pouzolzia indica methanolic extract and Virkon® against cysts of Acanthamoeba spp. Southeast Asian J Trop Med Public Health 41(4): 776-784.

55. Gasparini R, Pozzi T, Magnelli R, Fatighenti D, Giotti E, et al. (1995) Evaluation of in vitro efficacy of the disinfectant Virkon. Eur J Epidemiol 11(2): 193-197.

56. Moreton JA, Trevor H (1999) Use of Virkon® as a disinfectant for clinical samples carrying a high risk of infection in inductively coupled plasma mass spectrometry. Annal At Spect 14: 893-894.

57. Chu Dan-My, Miles H, Toney D, Ngyuen Chi, Marciano-CF (1998) Amebicidal activity of plant extracts from Southeast Asia on Acanthamoeba spp. Parasitol Res 84(9): 746-752.

58. Malatyali E, Tepe B, Degerli S, Berk S, Akpulat HA (2012) In vitro amoebicidal activity of four Peucedanum species on Acanthamoeba castellanii cysts and trophozoites. Parasitol Res 110(1): 167-174.

59. Degerli S, Berk S, Malatyali E, Tepe B (2012) Screening of the in vitro amoebicidal activities of Pastinaca armenea (Fisch. \& C.A.Mey.) and Inula oculus-christi (L.) on Acanthamoeba castellanii cysts and trophozoites. Parasitol Res 110(2): 565-570.

60. Malatyali E, Tepe B, Degerli S, Berk S (2012) In vitro amoebicidal activities of Satureja cuneifolia and Melissa officinalis on Acanthamoeba castellanii cysts and trophozoites. Parasitol Res 110(6): 2175-2180.

61. Tepe B, Malatyali E, Degerli S, Berk S (2012) In vitro amoebicidal activities of Teucrium polium and T. chamaedrys on Acanthamoeba castellanii trophozoites and cysts. Parasitol Res 110(5): 1773-1778.

62. Derda M, Hadaś E, Thiem B (2009) Plant extracts as natural amoebicidal agents. Parasitol Res 104: 705-708.

63. Grabely S, Thiericke R (1999) Bioactive agents from natural sources: Trends in discovery and application. Adv Biochem Eng Biotech 64: 101-154.

64. Kayser O, Kiderlen AF, Croft SL (2003) Natural products as antiparasitic drugs. Parasitol Res 90: S55-S62.

65. Mazur T, Hadas E, Iwanicka I (1995) The duration of the cyst stage and the viability and virulence of Acanthamoeba isolates. Trop Med Parasitol 46(2): 106-108.

66. Ficker L, Seal D, Warhurst D, Wright P (1990) Acanthamoeba keratitis: resistance to medical therapy. Eye 4(Pt 6): 835-838.

\section{Your next submission with Juniper Publishers} will reach you the below assets

- Quality Editorial service

- Swift Peer Review

- Reprints availability

- E-prints Service

- Manuscript Podcast for convenient understanding

- Global attainment for your research

- Manuscript accessibility in different formats

( Pdf, E-pub, Full Text, Audio)

- Unceasing customer service

Track the below URL for one-step submission

https://juniperpublishers.com/online-submission.php 